\title{
Milligram Per Milliliter Per Milligram Per Kilogram
}

National Cancer Institute

\section{Source}

National Cancer Institute. Milligram Per Milliliter Per Milligram Per Kilogram. NCI

Thesaurus. Code C105475.

A dose calculation unit expressed in milligrams per milliliter, divided by milligram per kilogram. 